UDC 811.11-112

doi: 10.22250/2410-7190_2021_7_1_86_95

\author{
Maria N. Kovaleva \\ Northern (Arctic) Federal University named after M.V. Lomonosov \\ Archangelsk, Russian Federation \\ m.kovaleva@narfu.ru
}

\title{
The conative function of constructions expressing surprise in Swedish, English and Russian
}

\begin{abstract}
The article presents the results of a comprehensive comparative analysis of the concept "surprise" in Swedish, English and Russian fiction books manifested by syntactic constructions performing the conative function. Three Swedish fiction novels by Selma Lagerlöf and their translations into English and Russian were chosen as the material for the study. 135 complexes of examples $(1$ complex $=1$ Swedish token +1 corresponding English token +1 corresponding Russian token) were selected using continuous sampling method. First, it was found that the function could be manifested in 2 directions (modes): extroversion and introversion. Second, 2 syntactic patterns expressing the function were identified: imperatives and vocatives. The analysis of their interaction in the three languages showed the following results. In Swedish and Russian, the introverted imperative pattern was used while in English modal verb+infinitive extraverted pattern was mostly used. As far as vocatives, similarly to imperatives, both extroversive and introversive modes were present. However, in contrast to imperative patterns, introversive mode prevailed in vocatives in all the three languages. Further studies might involve comparative analysis of the modes and patterns manifesting surprise in other languages of origin.
\end{abstract}

Keywords: emotion, surprise, conative function, comparative analysis, fiction.

(C) Kovaleva M. N. 2021

For citation: Kovaleva, M. N. The conative function of constructions expressing surprise in Swedish, English and Russian. Teoreticheskaya i prikladnaya lingvistika [Theoretical and Applied Linguistics], 7 (1), 86-95. doi: 10.22250/2410-7190_2021_7_1_86_95.

\section{Introduction}

Being one of the fundamental emotions, surprise is an important characteristic of a person, since it predetermines a person's knowledge and contributes to his development. Despite the fact that the emotion of surprise is one of the cultural components, it manifests a certain specificity of verbalization in various languages. This specificity, which is of undoubted interest for linguistics, is largely determined by the subjectivity of the reality perception.

The emotion of surprise has been the object of attention of many foreign and Russian scientists. Researchers studied this emotion through the metalanguage [Apresyan, 1993; Iordanskaya, 1970; Vezhbitskaya, 1996], analyzed the specifics of textual realization of surprise in English [Adamchuk, 1996], described various means of expression of surprise [Korlykhanova, 2000], compared the partial expression of surprise in English and German [Kolayan, 1999; Short, 1987 ; Smagin, 1998]. However, according to our data, at the present stage of studying the emotion of surprise, a comprehensive analysis of the conative function of constructions expressing surprise in Swedish, English and Russian has not yet been carried out. This fact motivated the current study. Thus, the three-fold goal of this article is to describe the conative function of the emotion of surprise, to conduct a comparative analysis of these structures in Swedish, English and Russian, as well as to identify the similarities and differences in performing the function in the three languages. 
In the traditional language model, described in detail by $\mathrm{K}$. Buhler, three functions were distinguished: emotive, conative and referential. The scientist identified three central subjects in speech according to each function: the one who speaks (first subject), the one who listens (second subject), someone or something who or what is talked about (third subject) [Buhler, 1933, p. 19-90].

R. Jacobson supplemented this classification and outlined six language functions, linking each of them with a certain part of the communication process [Jacobson, 1975]. R. Jacobson defined the following factors as necessary elements of speech communication: addresser, addressee, context, message, contact (between the addresser and the addressee), message transmission, and code. According to the scientist, each of them corresponded to a special function of the language, the conative being one of them [Jacobson, 1975, p. 198].

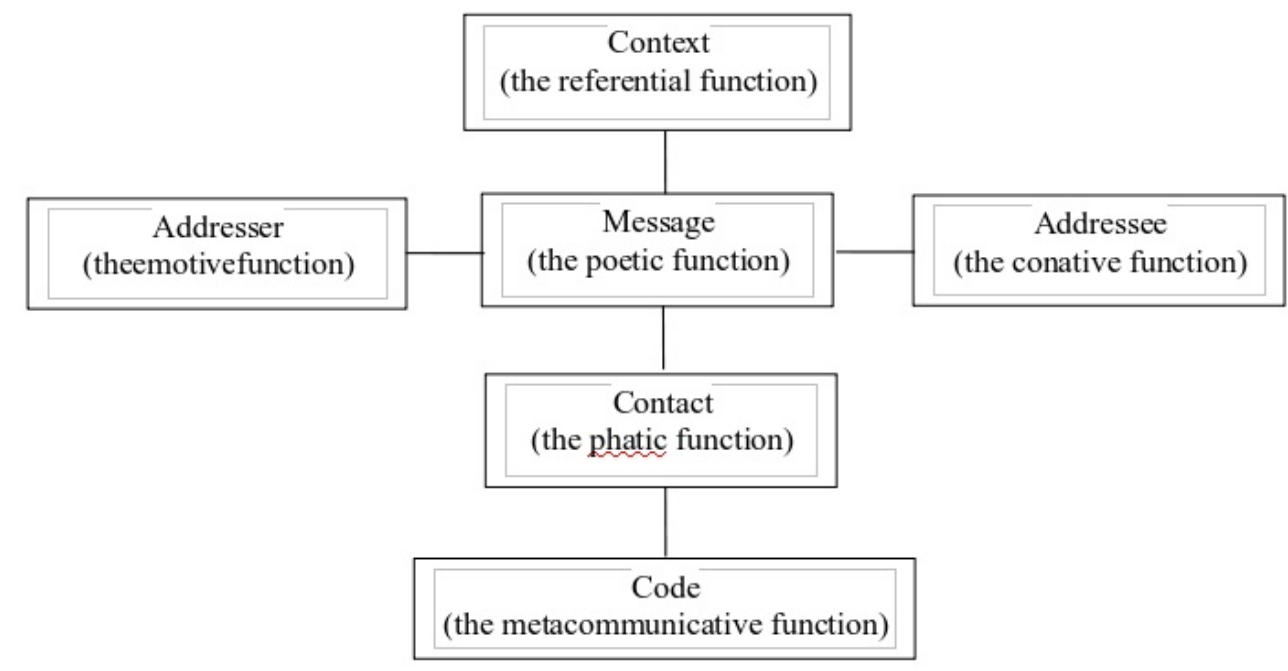

F i g u r e 1. Language functions according to R. Jacobson

Figure 1 illustrates that the conative function of the language is associated with the addressee. This function is expressed grammatically by vocative and imperative constructions, which deviate phonologically, morphologically, and syntactically from other nominal and verbal categories. Imperative constructions are not equal to statements because they cannot be considered in terms of true or false [Jacobson, 1975, p. 201]. In this article, the conative function of the language will be examined through the constructions expressing surprise.

Before proceeding to experimental part of the paper, it is necessary to distinguish the definitions of the imperative and the vocative constructions.

The imperative means an attempt of the speaker to force someone to commit or not to commit some action by his statement [Dobrushina, 2016, p. 161]. In most cases, the addressee of such statement is the listener, the second-person singular, and the situation indicated by the imperative does not belong to reality. The imperative is used to make order, to ask, advise, allow or inform that the speaker does not interfere with the performance of a certain action [Dobrushina, 2016, p. 194].

The vocative form is referred to as the vocative case or just vocative. Scientists define a vocative as a special type of one-component sentences [Abakumov, 1942; Shakhmatov, 1941]. The definition of a vocative as a special form of name, which is used to identify the object that is being accessed, seems more complex [Reformatskiy, 1998]. Linguists agree that vocative sentences are the appeals, and, at the same time, they are meaningful and complete sentences due to the rich content that is concentrated in the appeal. Such compellation not only calls the addressee, but at the same time partially or completely conveys the content of speech [Moiseeva-Pron, 2016, p. 210]. 


\section{Materials and Methods}

The research material was taken from the fiction books in Swedish, as well as their translations into English and Russian. During the experimental part of the study, the trilogy of the Swedish author Selma Lagerlöf (Löwensköldska ringen, Charlotte Löwensköld and Anna Svärd [Lagerlöf, $1978 \mathrm{a}, \mathrm{b}$ c]) was analyzed. The translation into English was done by L. Schenck [Lagerlöf, 2011, 2014, 2016]. The translation into Russian was made by a group of authors: L. Braude, N. Belyakova, F. Zolotarevskaya [Lagerlöf, 2007].

Continuous sampling method was used in the course of the experiment to collect the data that formed the corpus for the study. As a result, the corpus included 135 complexes of examples representing syntactic constructions that express surprise. One complex comprised 1 original token in Swedish, 1 token of its translation into English and 1 token of its translation into Russian). The selected tokens were identified as imperative and vocative syntactic constructions that were subjected to further analysis that included comparing the frequency of the patterns between the languages.

\section{Results and discussion}

The analysis of the selected language material enabled to identify two ways of expressing the conative function in constructions conveying surprise. This function can be displayed through imperatives and vocatives.

\subsection{Imperatives}

During the analysis, 35 text fragments with the emotion of surprise, expressed through the imperative, were found. The imperative in these complexes of examples has a different orientation: some of them are aimed at the listener, others - at the speaker himself. Thus, all imperative constructions in Swedish, English, and Russian that express surprise were examined not only from the position of the imperative's functionality, but also from the point of their orientation.

One of the examples expressing the extroversive orientation of the imperative is presented in the complex (1):

(1) Swedish: Jag såg, att de hade satt ner en liten stege i graven i förmiddags, sade hustrun, men den åtminstone måtte väl vara borttagen.

- Jag skall minsann se efter, sade mannen och famlade sig fram till gravhålet. Nej, tänk du! brast han ut. Det här går då över alla gränser. Stegen står kvar här [Lagerlöf, 1978 a, p. 12-13].

English: 'I noticed this morning that there was a little ladder down into it,' said his wife, 'But they must at least have taken that away'.

'I'll just see about that,' said Bård, fumbling his way to the hole. 'Would you believe it?' he exclaimed. 'This is the limit. The ladder's still here!' [Lagerlöf, 2011, p. 23].

Russian: Нынче утром я видала, как они опустили в склеп лесенку, - сказала жена. - Но её уж, поди, убрали.

- А погляжу-ка я и в самом деле, - сказал муж и стал шарить руками в могильном проломе. - Нет, гляди-ка ты! - воскликнул он. - Слыхано ли дело! Лесенкаmо ещё mym! [Lagerlöf, 2007, p. 32].

In this set of examples, the conative function of the construction expressing surprise is represented by the imperative in Swedish and Russian which is used to make the interlocutor pay attention to what is happening: Nej, tänk $d u$ ! in the language of origin and Hem, гляди-ка mbl! in the language of translation. In English, the rhetorical question Would you believe it? is used instead of the imperative, that indicates a lesser degree of expressed directivity. In all 
compared languages, the appeal is directed to the second-person singular enabling to conclude that the analyzed constructions have extroversive orientation.

Cases of using the imperative are also outlined in the complex of examples (2):

(2) Swedish: Då Charlotte kom inrusande för att sätta sig till matbordet, där de andra redan hade tagit plats, möttes hon av ett strängt tillrop från prostinnan.

- Tänker du sätta dig till bords med de där fingrarna?

(Charlotte såg ner på sina händer, som verkligen var förfärligt nerbläckade efter den ivriga skrivningen) [Lagerlöf, 1978 b, p. 89].

English: When Charlotte hurried into the room to take her place at the table where the others were already seated, she was met with a firm reprimand from the pastor's wife:

'Were you thinking of sitting down with fingers like that?' [Lagerlöf, 2014, p. 93].

Russian: Когда Шарлотта вбежала в столовую, все остальные уже сидели за столом. Она хотела было занять своё место, но её остановило строгое восклицание пастории:

- И ты собираешься сесть за стол с такими руками?

(Шарлотта взглянула на свои пальцы, которые и впрямь были донельзя измараны чернилами после усердного писания) [Lagerlöf, 2007, p. 197].

In the given complex of examples, surprise is presented in the form of a hidden imperative, displayed by a rhetorical question. In the language of origin and in the languages of translation, an appeal is made to Charlotte with a call to action (to wash her hands) and a forbidding of doing what she wanted to do (to sit down at the table). The reflection of the conative function in these examples is expressed by using the imperative. In this case the extravertivity of the imperative is outlined in all the three languages.

The extroversive orientation of the imperative in constructions expressing surprise can also be considered on a set of examples (3):

(3) Swedish: Charlotte, som efter sitt giftermål hade lagt sig till med ovanan att stiga sent upp, kom nästa dag inte till synes förrän vid frukosten. Prostinnan hade då redan varit på benen ett par timmar. Hon hade gjort en tur kring gården, stått vid grinden och beskådat den kära utsikten neråt sjön och kyrkan samt även språkat med de förbigående och insamlat nyheter.

- Kan du tänka dig, Charlotte! sade hon. Den där Karl-Artur! Ja, jag kan inte hjälpa, att jag håller av honom, men han är $i$ alla fall inte annat än sig lik.

Därpå berättade hon, att Karl-Artur hade begått en sådan horribel dumhet som att låta de tio barnen flytta ifrån honom.

Charlotte satt där alldeles handfallen [Lagerlöf, 1978 c, p. 182].

English: Charlotte, who, after her marriage, had taken to rising late, did not appear the next morning until breakfast time. Mrs. Forsius had already been up and about for a couple of hours by then. She had inspected the property, stood by the gate and gazed at her favourite view of the lake and the church, and even conversed with passersby to gather news.

'Can you imagine, Charlotte? That Karl-Artur!' she exclaimed. 'I cannot help being fond of him, but he is behaving entirely true to form.'

She went on to tell Charlotte that Karl-Artur had commited the horrendously foolish mistake of letting the ten children to move out on him.

Charlotte sat there at a loss [Lagerlöf, 2016, p. 192].

Russian: Шарлотта, у которой после замужества появилась дурная привычка поздно вставать, на следуюший день вышла только к завтраку. Пасторша к тому времени была на ногах уже несколько часов. Она обошла усадьбу, постояла у калитки, созериая любимый ею вид на озеро и иерковь, потолковала с прохожими и разузнала все новости. 
- Тьл только подумай, Шарлотта, - сказала она, - что натворил этот КарлАртур! Я люблю его, ничего не поделаешь, однако он, как всегда, верен себе!

Затем она рассказала, что Карл-Артур совершил ужсасную глупость, позволив десяти ребятишкам уехать от него.

Шарлотта сидела, как громом поражённая [Lagerlöf, 2007, p. 524].

The pastor's wife tells Charlotte the terrible story about Karl-Arthur, who was the girl's fiance. However, the conative function in this complex is presented differently in three compared languages: the exclamative and interrogative constructions are used to express surprise in the language of origin and its translation into English (Kan du tänka dig, Charlotte!, Can you imagine, Charlotte?), while in Russian the imperative is applied (Tbl только подумай, Шарлотта). It is made not only to attract but also to focus the girl's attention on what the pastor's wife is going to tell her.

In the following set of examples (4), however, the conative function is oriented not only to the listener, but also to the speaker himself:

(4) Swedish: Han gick åter fram till jungfrun.

- Tänk, att det är över! sade han och såg helt glad ut. Det går över, bara jag säger, att jag vill lida mitt straff. Jag är så lycklig [Lagerlöf, 1978 c, p. 21].

English: He walked up to the housekeeper.

'Just think, my seizure is over!' he said, looking very pleased. 'It passed as soon as I said that I am prepared to serve my time. I am so relieved' [Lagerlöf, 2016, p. 29].

Russian: Он снова подошёл к служанке.

- Подумать только, прошло! - сказал он радостно. - Как только скажу, что хочу, чтоб меня покарали, сразу боль унимается. Я совершенно счастлив [Lagerlöf, 2007, p. 378].

While in Swedish and English the orientation of the imperative construction to the second-person singular is maintained (Tänk ..., Just think ...), in the Russian translation the expression «Подумать только...» is presented, in which the author refers to himself. The orientation of the statement to the author himself reflects the introvertivity of the imperative. The speaker expresses an extreme degree of surprise, bordering on distrust of what is happening. A similar situation can be found in the complex of examples (5), in which, however, there is no imperativeness in the language of origin:

(5) Swedish: Inte förrän alltsammans var över, gav Anna Svärd mor sin en liten vink, och gumman började genast.

- Anna här är liksom schinerad å säga't själv. Men det har hänt'na ett så stort under. Hon ska bli gift mä en präst nere $i$ Värmland.

- Men va hör jag! sade Ris Ingborg. Ska hon gift sej? [Lagerlöf, 1978 c, p. 47].

English: Not until they were all finished did Anna Svärd give her mother a little sign, and the old woman began straight away:

'Anna's a bit embarrassed to tell you herself. But the most amazing miracle has happened. She's to marry a pastor down in Värmland'.

'I can hardly believe my ears,' exclaimed Ingborg. 'Getting married?' [Lagerlöf, 2016, p. 55].

Russian: Только когда они напились кофе, Анна Сверд подала матери знак, и старуха сразу же начала:

- Анна-то сама вроде совестится сказать. Ведь с ней чудо приключилось несльхханное. За пастора в Вермланде выходит.

- Подумать только! - сказала Рис Ингборг. - Неужто Анна замуж выходит? [Lagerlöf, 2007, p. 402]. 
In the mentioned constructions expressing surprise, the conative function in Swedish and Russian is shown in the form of a self-talk (Mеn va hör jag!; Подумать только!), while in English the affirmative sentence with a modal verb is used (I can hardly believe my ears). In English translation there is no imperative, while in the language of origin and in Russian translation introverted imperative is used.

\subsection{Vocatives}

During the research, 30 vocative constructions with the emotion of surprise were identified. As in the analysis above, vocatives were also considered in terms of their extroversive and introversive orientation. Besides, vocatives functionality in Swedish, English, and Russian was considered.

One of the examples expressing the introversive orientation of the vocative is presented in the complex (6):

(6) Swedish: - Men, sade hustrun och tvärstannade, vad är det jag ser? Börjar det redan på att dagas? Det ser så ljust ut $i$ öster.

- Nej, inte kan det redan vara solen, som kommer, sade bonden. Det måtte vara eldsvåda. Det är, som om det skulle vara åt Olsbyhållet. Måtte det inte...

Han avbröts av ett högt skrik från hustrun.

- Det är hos oss det brinner, skrek hon. Det är Mellomstuga, som brinner. Generalen har satt eld på den [Lagerlöf, 1978 a, p. 16].

English: 'But,' said his wife, coming to a sudden halt, 'what's that I see? Can it already be sunrise? It's so light in the east!'

'It can 't possibly be morning yet,' said the farmer. 'There must be a fire. Looks as if it's over Olsby way. It couldn't be...'

His wife's piercing scream cut him short.

'It's our place that's on fire. Mellomstuga's on fire. The General's set fire to it' [Lagerlöf, 2011, p. 25].

Russian: - A это что? - внезапно остановившись, спросила жена. - Что я вижу? Неужто заря занимается? На востоке-то вроде светает!

- Нет, солниу ещзё рано вставать, - сказал крестьянин. - Видать - пожар. И вроде бы где-то в стороне Ольсбю. Уж не...

Его прервал громкий крик жень.

- Это у нас горит! - кричала она. - Мелломстуга горит! Генерал поджёг её! [Lagerlöf, 2007, p. 34].

In the considered complex of examples, vocative constructions, where the speaker himself is both the addresser and addressee, are outlined. The peasant's wife is so amazed at what she saw that she is gripped by involuntary horror from the supposed conjecture. She cannot believe it and asks herself a question. In the language of origin, this question is conveyed by the following construction: Vad är det jag ser?, in translation into English: What's that I see?, and in translation into Russian: Что я вижу? The purpose of this question is not to obtain information; the emotion shown in this example is expressed through a vocative. The conative function in the examples is displayed as a question of the addresser to herself.

In the sets of examples (7) and (8) the conative function is represented by an appeal to God, through which a high degree of surprise of the speaker is featured:

(7) Swedish: - Vad var det jag sa? började han. Far håller på att berätta för prosten, att det var mor och han, som stal kungaringen från gamle general Löwensköld.

- A, Gud sig förbarme! utbrast systern. Skall vi inte tala om för prosten, att det är lögn, att det bara är sådant, som han diktar på sig? [Lagerlöf, 1978 a, p. 24]. 
English: 'What did I tell you?' he began. 'Father's telling the pastor that Mother and he stole the royal ring from old General Löwensköld.'

'God have mercy on us then!' his sister exclaimed. 'Shouldn't we tell the pastor it's a lie, just something he's making up?' [Lagerlöf, 2011, p. 32].

Russian: - Ну, что я говорил? - начал он. - Отеи рассказывает пастору, что это они вместе с матушкой украли королевский перстень у старого генерала Лёвеншёльда.

- Господи помилуй! - воскликнула сестра. - Уж не сказать ли нам пастору, что все это небылицы, что он сам на себя напраслину возводит [Lagerlöf, 2007, p. 41].

(8) Swedish: - Det är en enkel, fattig människa, Charlotte. Charlotte ska inte tänka på någon av sina fina bekantskaper.

- Det kan väl aldrig...! Hon ropade till så häftigt, att han måste se på henne. Det rörliga ansiktet uttryckte verkligen den högsta förskräckelse.

- Den där dalkullan, som var inne i köket i går... Gud i himlen, Karl-Artur! Jag tycker mig ha hört sägas, att hon heter Anna Svärd [Lagerlöf, 1978 b, p. 69].

English: 'She is a simple woman, Charlotte, from simple circumstances. I suggest you stop thinking in terms of your fine acquaintances.'

'You can't possibly mean...!' she cried with such vehemence he had to look at her. Her face, which always gave her away, truly reflected the greatest horror.

'That Dalarna peddler who came by the kitchen yesterday... God in heaven, KarlArtur! I do believe I heard someone say her name was Anna Svärd' [Lagerlöf, 2014, p. 82].

Russian: - Тебе незачем перебирать в уме своих образованных подруг. Это простая, бедная девушка, Шарлотта.

- Как! Неужели... - Она выкрикнула эти слова с таким волнением, что он невольно взглянул на неё. На её подвижном лице отобразился испуг.

- Неужели это... та самая далекарлийка, что была вчера у нас на кухне!.. Боже милостивый! Карл-Артур, я, кажется, припоминаю: кто-то говорил, что её зовут Анна Сверд [Lagerlöf, 2007, p. 178].

In these examples, an appeal to God is a direct expression of the extreme degree of surprise, bordering on fear. In the complex of examples (7), the daughter finds out that the dying father is hiding a terrible secret. It both surprises her, as previously she considered her father to be the most honest person, and also horrifies, because at confession her father did not confess his sins. Vocatives Gud sig förbarme! in Swedish, Господи помилуй! in Russian, God have mercy on us then! in English convey not only an appeal to God but also a request for forgiveness and protection.

The group of examples (8) also indicates an appeal to God both in the language of origin and in the languages of translation, however, the function of surprise is presented differently here. Charlotte learns that her beloved Karl-Arthur, with whom they had a quarrel, is going to marry a girl he met by chance, whom he does not love, and whose social status is much lower than his. Karl-Arthur does this to spite Charlotte, and that provokes her surprise, mixed with feelings of excitement and fear. Charlotte speaks to God because she is afraid of what can happen to Karl-Arthur and how his life can be changed.

In the complexes of examples (7) and (8) the conative function is conveyed by appeals to God, thus, in these examples, extraverted vocatives are highlighted.

In the set of examples (9) the conative function is aimed at expressing surprise as well. However, the direction of the impact in the compared languages differs:

(9) Swedish: - Vad du säger! utropade prostinnan. Den hustrun! Har hon gått sin väg? Vem ska då hålla ordning på honom?

I själva verket tycktes alla de, som bevistade sammanträdet, ha gjort sig samma fråga [Lagerlöf, 1978 c, p. 195]. 
English: 'What am I hearing!' cried Mrs. Forsius. 'His wife! Gone away? Oh, who will keep him in check now?'

In fact, everyone at the meeting appeared to have asked himself the same question [Lagerlöf, 2016, p. 206].

Russian: - Что mы говоришь! - воскликнула пасторша. - Неужто его жена ушла? Кто же тогда станет заботиться о нём?

Надо сказать, что все присутствовавшие на собрании, казалось, задавали себе тот же вопрос [Lagerlöf, 2007, p. 537].

In the language of origin and in its Russian translation, the message is made for the addressee, an extroversive vocative is presented here: Vad du säger! in Swedish and Что ты говоришь! in Russian, while English translation uses an exclamative construction with the applying of the addresser to himself: What am I hearing! The author expresses a high degree of surprise, bordering on a distrust of what he hears through the vocatives.

\section{Conclusion}

The results obtained during the experiment made it possible to draw several conclusions regarding the methods for expressing the conative function in constructions conveying surprise and its features in Swedish, English, and Russian. First, considering the function from the point of view of its direction, we can distinguish extroverted and introverted orientation. However, this orientation is presented differently in the analyzed languages. Thus, the introversion of the conative function is traced in the selected examples in language of origin and translation into Russian, while in English they reflect extroverted orientation.

Another important aspect is the semantic message of vocative constructions. In the set of examples examined, the following meanings of imperatives were revealed: drawing attention to what is happening, focusing attention of an addressee, call to action, prohibiting the action, maximizing surprise, reflecting emotions bordering on an emotion of surprise (fear, horror, distrust). Summing up the analysis of vocative constructions expressing an emotion of surprise, it is necessary to note extroversive and introversive orientations similar to imperatives. However, in contrast to imperative constructions, introversive orientation prevails in vocatives in all the three languages. In the analysis of the conative function of vocative constructions, the following semantic messages were revealed: expression of extreme degree of surprise, reflection of emotions bordering on an emotion of surprise (fear, horror, distrust directed at both the addresser and the addressee), calls to God with a prayer for help and protection.

In the future, similar studies could be performed of the conative function in constructions expressing surprise in fiction books, where the languages of origin would be English and Russian. Further comparative analysis of the obtained results on different languages of origin might provide an interesting insight into the issue.

\section{Illustration material resources}

Lagerlöf, S. (1978 a). Löwensköldska ringen. Stokholm, Albert Bonniers förlag AB.

Lagerlöf, S. (1978 b). Charlotte Löwensköld. Stokholm, Albert Bonniers förlag AB.

Lagerlöf, S. (1978 c). Anna Svärd. Stokholm, Albert Bonniers förlag AB.

Lagerlöf, S. (2007). Persten' Levenshel'dov [The Löwensköld Ring]. Translated into Russian by

L. Braude, N. Belyakova, F. Zolotarevskaya]. Moscow.

Lagerlöf, S. (2011). The Löwensköld Ring. Translated into English by L. Schenck. Norvik Press. Lagerlöf, S. (2014). Charlotte Löwensköld. Translated into English by L. Schenck]. Norvik Press. Lagerlöf, S. (2016). Anna Svärd. Translated into English by L. Schenck]. Norvik Press. 


\title{
References
}

Abakumov, S. I. (1942). Sovremennyy russkiy literaturnyy yazyk [Modern Russian literary language]. Moscow.

Buhler, K. (1933). Die Axiomatik der Sprachwissenschaft [The Axiomatics of Linguistics]. KantStudien [Kant studies], 38 (1-2), 19-90.

Dobrushina, N. R. (2016). Povelitel'noe naklonenie [The Imperative mood]. In V. A. Plungyan (Ed.), Materialy k Korpusnoy grammatike russkogo yazyka. Glagol [Materials for the Corpus Grammar of the Russian language. Verb] (Part I, pp. 161-210). St Petersburg : Nestor-Istoriya Press.

Jacobson, R. (1975). Lingvistika i poetika [Linguistics and Poetics]. In E. Ya. Basina, M. Ya. Polyakova (Eds), Strukturalizm: «za» $i$ «protiv» [Structuralism: Pros and Cons] (pp. 193-231). Moscow: Progress Press.

Moiseeva-Pron, N. V. (2016). K voprosu o statuse vokativnogo predlozheniya (na materiale khudozhestvennoy prozy A. P. Chekhova) [To the question of the status vocative proposals (Based on the fiction of A.P. Chekhov)]. IXMezhdunarodnye Sevastopol'skie Kirillo-Mefodievskie chteniya [IX International Sevastopol Cyril and Methodius Readings] A collection of scientific papers (pp. 208-216). Moscow : Pero Press.

Reformatskiy, A. A. (1998). Vvedenie v yazykovedenie [Introduction to Linguistics]. Moscow.

Shakhmatov, A. A. (1941). Sintaksis russkogo yazyka [The syntax of the Russian language]. Moscow.

УДК 811.11-112

doi: 10.22250/2410-7190_2021_7_1_86_95

Ковалева Мария Николаевна

Северный (Арктический) федеральный университет имени М.В. Ломоносова

г. Архангельск, Российская Федерация

m.kovaleva@narfu.ru

\section{Конативная функция конструкций, выражающих удивление, в шведском, англииском и русском языках}

\begin{abstract}
Аннотация
В статье представлены результаты комплексного сопоставительного анализа концепта удивления в шведской, английской и русской художественной литературе, проявляющегося в синтаксических конструкциях, выполняющих конативную функцию. Материалом для исследования послужили три шведских художественных романа Сельмы Лагерлёф и их переводы на английский и русский языки. 135 комплексов примеров $(1$ комплекс $=1$ шведский пример +1 соответствующий английский пример +1 соответствующий русский пример) были отобраны методом сплошной выборки. В ходе исследования выяснилось, что вопервых, конативная функция может проявляться в двух направлениях: экстравертивном и интровертивном. Во-вторых, были идентифицированы два синтаксических паттерна, выражающих эту функцию - императивы и вокативы. Анализ их взаимодействия в трёх языках показал следующие результаты. В шведском и русском языках использовалась повелительная форма интровертивной направленности, а в английском конструкция «модальный глагол + инфинитив» экстравертивной направленности. Вокативы, по аналогии с императивами, были представлены как экстравертивной, так и интровертивной направленностью. Однако, в отличие от императивных конструкций, интровертивная направленность преобладала в вокативе во всех трёх языках. Перспективу исследования может составить сравнительный анализ способов и моделей проявления удивления в произведениях на других языках оригиналов.
\end{abstract}

Ключевые слова: эмоция, удивление, конативная функция, сравнительный анализ, художественная литература.

(C) Ковалева М. Н. 2021 
Для цитирования: Kovaleva M. N. The conative function of constructions expressing surprise in Swedish, English and Russian.// Теоретическая и прикладная лингвистика. 2021. Вып. 7, №1. С. 86-95. doi: 10.22250/2410-7190_2021_7_1_86_95.

\section{Источники иллюстративного материала}

Lagerlöf, 1978 a - Lagerlöf S. Löwensköldska ringen. Stokholm : Albert Bonniers förlag AB, 1978. 95 c. Lagerlöf, 1978 b - Lagerlöf S. Charlotte Löwensköld. Stokholm : Albert Bonniers förlag AB, 1978. 259 c. Lagerlöf, 1978 c - Lagerlöf S. Anna Svärd. Stokholm : Albert Bonniers förlag AB, 1978. 301 c.

Лагерлёф, 2007 - Лагерлёф С. Перстень Лёвеншёльдов / пер. со швед. Л. Брауде, Н. Беляковой, Ф. Золотаревской. М. : Эксмо, 2007. 656 c.

Lagerlöf, 2011 - Lagerlöf S. The Löwensköld Ring / Translated into English by L. Schenck. Norvik Press, 2011. $120 \mathrm{p}$.

Lagerlöf, 2014 - Lagerlöf S. Charlotte Löwensköld / Translated into English by L. Schenck. Norvik Press, 2014. $290 \mathrm{p}$.

Lagerlöf, 2016 - Lagerlöf S. Anna Svärd / Translated into English by L. Schenck. Norvik Press, 2016. $330 \mathrm{p}$.

\section{Список литературы}

Абакумов С. И. Современный русский литературный язык. М. : Советская наука, 1942. 182 с. Bühler, K. Die Axiomatik der Sprachwissenschaft // Kant-Studien. 1933. T. 38. №. 1-2. C. 19-90.

Добрушина Н. Р. Повелительное наклонение // Материалы к Корпусной грамматике русского языка. Глагол. Часть I / отв. ред. В. А. Плунгян. СПб. : Нестор-История, 2016. С. 161-210.

Моисеева-Пронь Н. В. К вопросу о статусе вокативного предложения (на материале художественной прозы А. П. Чехова) // IX Международные Севастопольские КириллоМефодиевские чтения : сб. науч. работ; Севастополь. М. : Изд-во «Перо», 2016. С. 208-216.

Реформатский А. А. Введение в языковедение. М. : Аспект Пресс, 1998. 448 с.

Шахматов А. А. Синтаксис русского языка. М., 1941.620 с.

Якобсон, Р. Лингвистика и поэтика // Структурализм: «за» и «против» / под ред. Е. Я. Басиной, М. Я. Поляковой. М. : Прогресс, 1975. С. 193-231. 